\title{
The Natural History of The Bahamas
}


, n P.

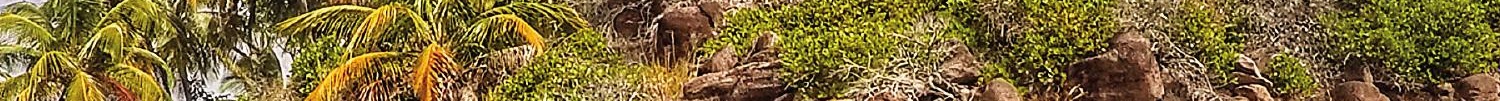

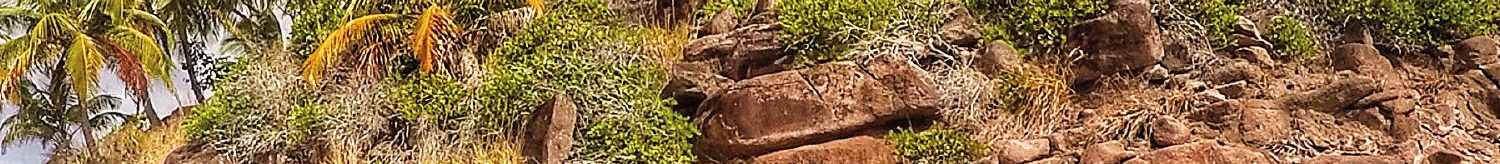

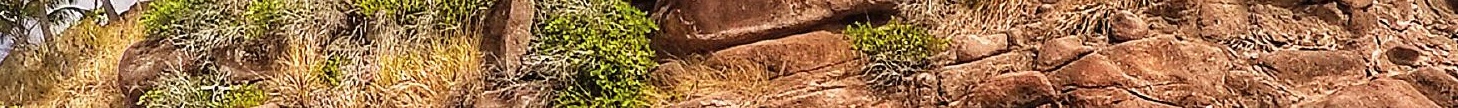

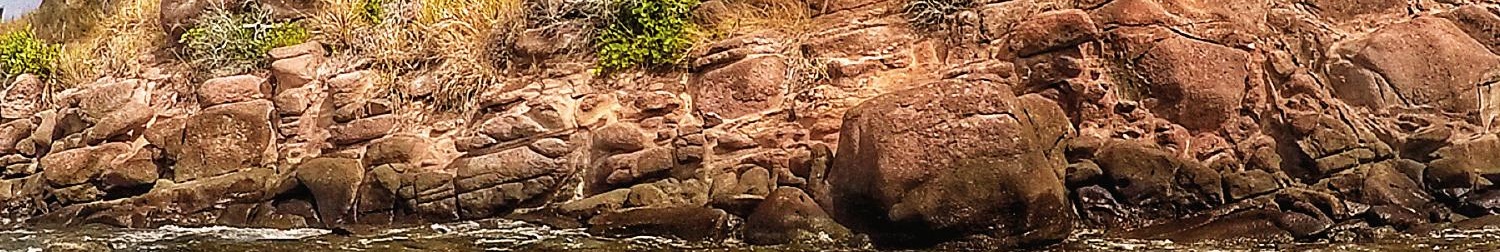
6 . -7.

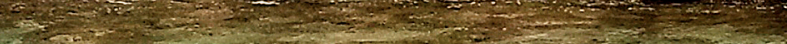

$$
\begin{aligned}
& x^{2}-x^{2} x^{2}=
\end{aligned}
$$

.5. - 395

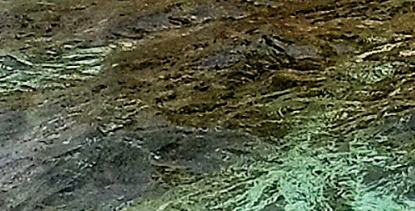

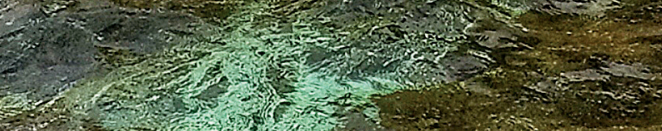

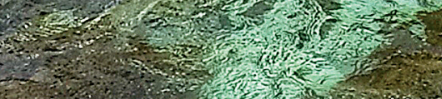
sitising

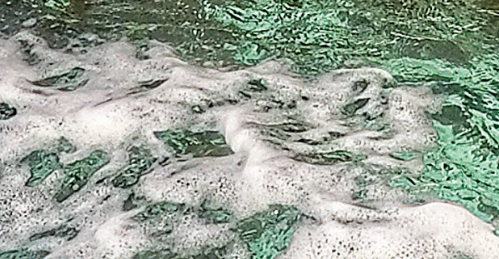




\section{The Natural History of The Bahamas}

\section{A FIELD GUIDE}

Dave Currie, Joseph M. Wunderle Jr., Ethan Freid,

David N. Ewert, and D. Jean Lodge

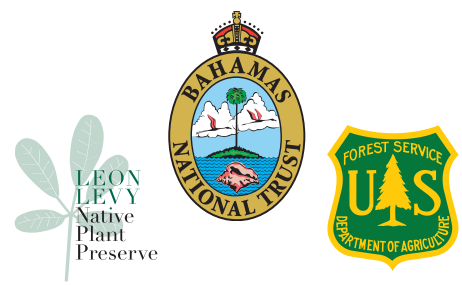

Comstock Publishing Associates

An imprint of

Cornell University Press

Ithaca and London 
Copyright (C) 2019 by Cornell University, with the exception of the section on fungi, portions of the introduction, photographs by Joseph M. Wunderle Jr., and illustrations and photographs by D. J. Lodge, which were written, drawn, and photographed by federal employees and cannot be copyrighted.

All rights reserved. Except for brief quotations in a review, this book, or parts thereof, must not be reproduced in any form without permission in writing from the publisher. For information, address Cornell University Press, Sage House, 512 East State Street, Ithaca, New York 14850. Visit our website at cornellpress.cornell.edu.

First published 2019 by Cornell University Press

Printed in China

Library of Congress Cataloging-in-Publication Data

Names: Currie, Dave 1967- author. | Wunderle, Joseph M., author. |

Freid, Ethan, author. | Ewert, David N., author. | Lodge, Deborah Jean, 1953-author.

Title: The natural history of the Bahamas : a field guide / Dave Currie, Joe M. Wunderle Jr., Ethan Freid, David N. Ewert, and D. Jean Lodge.

Description: Ithaca [New York] : Comstock Publishing Associates, an imprint of Cornell University Press, 2019. | Includes bibliographical references and index.

Identifiers: LCCN 2018035574 (print) | LCCN 2018035782 (ebook) | ISBN 9781501738029 (pdf) | ISBN 9781501738036 (epub/mobi) | ISBN 9781501713675 | ISBN 9781501713675 (pbk. ; alk. paper)

Subjects: LCSH: Natural history-Bahamas-Guidebooks. | Bahamas-Guidebooks.

Classification: LCC QH109.B3 (ebook) | LCC QH109.B3 C87 2019 (print) | DDC 508.7296-dc23

LC record available at https://lccn.loc.gov/2018035574

Front cover photos: (top) Cyclura rileyi rileyi, by Dave Currie; (bottom left) Melocactus intortus, by Ethan Freid; (bottom middle) Coereba flaveola bahamensis, by Bruce Hallett; (bottom right) Papilio andraemon, by Dave Currie. Spine photo: Setophaga flavescens, by Bruce Hallett.

Cover design and book design and composition by Julie Allred, BW\&A Books 
The Bahamas National Trust (BNT) was created by an act of Parliament in 1959 to build and manage the national parks system of The Bahamas. The BNT is a science-based organization dedicated to effectively managing national parks to conserve and protect Bahamian natural resources. This comprehensive network of effectively managed national parks and protected areas is important for biodiversity conservation, environmental education, and green spaces for public recreation. Today, 32 national parks are designated to protect more than 2 million acres of The Bahamas. The Trust is the only known nongovernmental organization in the world with the mandate to manage a country's entire national park system.

THE BAHAMAS NATIONAL TRUST

P.O. Box N-4105, Nassau, The Bahamas

242-393-1317•bnt@bnt.bs.www.bnt.bs 